\title{
Histochemical Studies of the Skin and Wool in Sheep Reared on High Molybdenum Diet
}

\author{
Naohiko IsHIDA and Ryoji Kawashima \\ Faculty of Agriculture, Kyoto University, Kyoto-shi 606
}

(Received August 13, 1973)

\begin{abstract}
Four Japanese Corriedale wethers were fed for 32 weeks in experimental conditions. Two of these were given $200 \mathrm{mg}$ ammonium molybdate per day per head and others were not given. The cortical segmentations were investigated at various levels from the skin surface. Evidence presented indicates that the administration of molybdenum (Mo) induces the irregularity in the cortical segmentation in the follicle of Mo treated sheep. Histochemical distributions of alkaline phosphatase and leucine aminopeptidase in the skin from these sheep were also studied.
\end{abstract}

It was previously shown that an excess of Mo in pastures induces similar symptoms as copper deficient ones in sheep, such as anemia, depressed growth, bone disorder, depigmentation of wool and some abnormal wool fibers. $1,2,3,4$ t

It is the current view that the physical properties of wool, including crimp are largely due to the existence of cystine residues. It provides disulphide cross links holding the polypeptide chains in the massive condition in the fiber. Disulphide cross links are produced by oxidation of thiol groups, which occurs during keratinization stage in fiber formation. MARSTON $^{6 /}$ found that the conversion of $-\mathrm{SH}$ to -SS- was incomplete in copper deficient sheep. While the role of copper in this situation is unknown, he suggested that copper seemes to play a role as a coenzyme in the oxidation of thiol groups. Recently, this idea has further supported by many other investigators. ${ }^{6,7}$ )

Moreover, it is well established that fine wool fibers have the bilateral structure constructed by ortho (basophilic) and para (acidophilic) cortical segments, which are different from each other in both chemical and physical properties. This has a close relationship to the crimp formation. $8,9,10$,

Though many investigations have been published about the chemical composition ${ }^{11,12,13)}$ or the physical properties,14) of the steely wool, there have been as yet little information about the effect of high Mo intake in sheep on the cortical segmentation at the lower level of the follicle.

The purposes of this study were to show the cortical segmentation at various levels of wool follicles from sheep maintained on a high Mo diet and also to obtain some informations about the localization of alkaline phosphatase and of leucine aminopeptidase. They are often found in the metabolically active parts in the animal tissues and considered likely to linked with the transport of organic substances.

Jap. J. Zootech. Sci., 45, (6) : 352-360. 


\section{Materials and Methods}

Four mature Japanese Corriedale wethers were used in this experiment. Each animal was kept in a single pen. The composition of the concentrate is alfalfa meal, wheat bran, and ground barley in 3:2:1 ratio by weight. Each animal was fed $200 \mathrm{~g}$ of hay and $700 \mathrm{~g}$ of the concentrate daily. Two of them were given $200 \mathrm{mg}$ ammonium molybdate per day per head for 32 weeks.

8 months later, wool and skin samples were taken from the mid shoulder of each sheep. Wool samples were repeatedly washed in petroleum ether, ethanol, and deionized water and finally air dried.

Samples of wool clot were embeded in $30 \%$ gelatin in $1 \%$ aquous solution of carbolic acid. Frozen sections ( $10 \mu$ thick) were cut perpendicularly to the fiber shaft in cryostat. The sections were stained with $0.1 \%$ methylene blue in $0.1 \mathrm{~mol}$ Tris buffer at $\mathrm{pH} 7.4$ for 8 hours at room temperature, differentiated in $0.1 \%$ acetic acid, and then investigated for dye distribution.

To study the cortical segmentation in the follicle, samples of the skin were fixed in ethanol-formalin solution for 48 hours and treated as usual. Longitudinal parafin sections were cut along the axes of the follicles, and transverse sections in serial sequence were cut at $8 \mu$ at nearly angles to the longer axes of follicles. Sections were stained with methylene blue in the same manner just as mentioned above and counterstained with haematoxylin and eosin if it is necessary.

The distributions of enzymes were investigated in serial frozen sections of fresh skin samples. Skin samples had been cut at $12 \mu$ in thickness in a cryostat and then fixed in cold acetone for 5 minutes. The sections were stained for alkaline phosphatase and leucine aminopeptidase, using metal precipitation method of GOMORI ${ }^{15)}$ and simultaneous coupling azo dye method by Burstone and FoLK, $^{16)}$ respectively.

\section{Results}

Fig. 1 shows the wool samples from the wethers which were reared for 8 months with high Mo diet (left 2 samples) and normal diet (right 2 samples). Accompanied with the continuous Mo intake, crimps have become more and more obscure and almost disappeared about 6 months later.

In the normal crimped wool from control sheep, the bilateral segmentations were observed in cortices of the wool (Fig. 2). Uptake of basic dye was practically limited to the ortho cortex. The boundaries between the ortho and the para segments were situated along the major axes of the elliptical fiber cross sections. The ortho cortex situated at the convex and the para cortex at concave side of the fiber curvature, as also observed in Fig. 3.

In contrast with the samples from control animals, the cortical segmentation of the straight wool fibers from Mo treated sheep varied from bilateral disposition of the two segments to irregular disposition of both. In some cases, the para segment was divided into two pieces by the ortho cortex which was located along the major axis of the elliptical fiber section. In others, the cortex was almost entirely occupied by the ortho cortex, where the para cortex barely remained in a peripheral part of the fiber section (Figs. 4 and 5). This abnormal 


\section{IsHIDA and KaWASHIMA}

segmentation was again observed in a longitudinal section (Fig. 6).

The abnormal cortical segmentations were observed in the fibers both large and small in diameter (Fig. 5). The appearance of the irregularity in cortical segmentation was out of all relation to the size of the fiber diameter.

The transverse section cut at various levels of the follicles from control sheep are shown in Fig. 7 to Fig. 9. In the lower part of the follicle bulb, the cells of the matrix which is the proliferative portion of wool follicle were colored dark blue (Fig. 7). These cells were stained more readily on the ectal side of the bulb deflection. In the upper part of the follicle bulb, the cells which had been differentiated from proliferative germinal layer were also stained blue.

Further up the follicle, the cells of the cortex were fibrillated and nuclei of these cells came to be remnant. The cells of Henle's layer of the inner root sheath colored light blue were completely hyalinized, while these of Huxley's layer were still cellular and contained many basophilic granules (Fig. 8). In the proximal region under this level of the follicle, there is no sign of bilateral staining in the cortex. In the section through the upper level of the keratogenous zone (Fig.9), the layers of the inner sheath were stained dark blue and there first appeared bilateral staining in the cortex, that is an half of the cortex were stained more densely on the thick side of the inner sheath than on the thin side. The differential staining in the cortex became more clear-cut in the upper half of the follicle.

The cortical segmentations from the lower level to the upper level of the keratogenous zone of the wool follicle from Mo treated sheep are shown in Fig. 10 to Fig. 12. The stain. ing pattern of the cortex from Mo treated sheep were quite different from those of control sheep. Although the position of the basophilic cortical cells in the section from control sheep (Fig. 9) was consistently associated with the thick side of the inner sheath, the dense baso. philic portions appear in the cortex from Mo treated sheep without relation to the inner sheath. In some cases, the uptake of basic dye of the cortical cells occured on the thin side of the inner sheath and in others, on the peripheral parts of the cortex (Figs. 10 and 11). These irregular staining pattern is again observed in a longitudinal section (Fig. 12) through keratogenous zone of the follicle of Mo treated sheep.

Such abnormal stainings as those observed in the cortex were also detected in Huxley's layer of the inner root sheath from Mo treated sheep. In Figs. 10 and 11, there are the interrupted dye uptake in Huxley's layer and the unstained parts of the layer are filled with small hyaline granules.

In the lower proximal region below the keratogenous zone, any differences in the histological nature could not be found between the control and Mo treated sheep (Figs. 13 and 14).

There was no appreciable difference in histological nature of the skin between two sheep within each group.

The distributions of leucine aminopeptidase and alkaline phosphatase are shown in Fig. 13 to 15 and Fig. 16 to 18 respectively. There was abundant aminopeptidase in the outer root sheath around the keratogenous zone (Fig. 13). The germinal matrix as well as the dermal papilla had much enzymatic reaction and the cortex above the level of the fibrilization was entirely negative (Fig. 14). Aminopeptidase activity was also observed in the secretory cells of sweat glands, in the periphery of the sebaseous glands, and the stratum malpighii of the epidermis (Fig. 15).

In the pilary systems, the dermal papillae and the blood capillaries that surrounded the 
Histochemical Studies of the Skin and Wool

wool follicles contained alkaline phosphatase (Fig. 16). The capillaries positive for alkaline phosphatase were often restricted to those closely associated with the follicle and they formed a dense network (Fig. 17) around the lower third of the follicles passing from the follicle network to the dermal papillae of the follicles (Fig. 18). Without the distributions of alka. line phosphatase in these region, the follicles were entirely negative.

Any differences in the activity and topographic localization of these enzymes in the skin between control and Mo treated sheep could not be observed throughout this histochemical study.

\section{Discussion}

The result obtained in this study is likely to indicate that the high molybdenum intake causes sheep to produce the wool which is mixed with considerable number of the fibers bearing irregular cortical segmentation. Previously, Fraser and Rogers ${ }^{17}$ found that when fibers are larger in diameter, the type of cortical segmentation changes from a bilateral structure to one of radial asymmetry. They concluded that these asymmetrical disposition of the ortho and the para cortex is closely related with the size of the fiber diameter and that the coarse wool fibers do not have a bilateral cortical segmentation.

However, the possible function of the fiber diameter to the type of cortical segmentation is unlikely because these irregular segmental patterns were observed both large and small fibers but not in control sheep in this experiment.

The cells of the follicle bulb have stronger affinity for methylene blue on the ectal side of the bulb deflection. The cytoplasmic basophilia is probably due to the ribonucleic acid $\left.{ }^{18}\right)$ and uneven dye uptake is likely to be the differences in the density of the cells which are mitotically active.

In the follicle from control sheep, the cells of the cortex gradually loose the affinity for basic dye on the thin side of the inner root sheath as the cells grow up in the keratogenous zone (Fig. 8 to 9). During this process, it is found in the cortical proteins that some acid groups are lost or modified as not to be bound by basic dye.

According to the summary of MONTAGNA, ${ }^{18}$ the first stained keratine fibrils in wool follicle are basophil in the $\mathrm{pH}$ range 3 to 7 and as they mature the keratine fibrils become strongly basophil and acidophil. In the state of fully keratinized, they are stained only by acidic dyes. Then the decreased affinity for basic dye may be taken as to indicate the degree of keratinization. Based on this interpretation, the preferential staining of the control wool follicle seemes to be in agreement with the findings of AUBER, ${ }^{19}$ i.e. the position of the fiber in the follicle of crimped wool is eccentric and the keratinization of the fiber starts on the side of the hair nearest the thinner part of the inner root sheath.

In the follicles from Mo treated sheep, decrease in the uptake of methylene blue occurs at random in both central and peripheral parts of the fiber cortex in the region of keratinization. This fact may suggest that some copper enzyme taken to be essential for oxidative transformation of $-\mathrm{SH}$ into $-\mathrm{S}-\mathrm{S}-$ bond ${ }^{5 /}$ may possibly be localized even in the central cells of cortex near the lower level of keratogenous zone.

This suggestion seems to be supported by some other previous reports. BRAWN-FALK $0^{201}$ demonstrated in the human hair follicle that besides a weak cytoplasmic reaction of the alloxan and ninhydrin-Schiff reagent in the keratogenous zone. It suggests him that the 


\section{IsHIDA and KaWASHIMA}

Keratogenous zone has great concentration of free amino acids, probably as a result of protein synthesis connected with an increase of short-chain proteins. More recently, BERSAQUEs and RothMAN ${ }^{211}$ found that several labeled amino acids including cystine were simultaneously incorporated into keratinized material in guinea pig. They posturated that keratine may be formed directly from free amino acids arising from hydrolysis of cellular proteins in the keratogenous zone.

In association with these previous reports, it seems to be recognized that Mo may affect on the keratine synthesis in the cortical cells during the maturation and consequently upset the cortical segmentation of fibers, although it is still unknown whether the function of Mo is direct or not.

The high concentration of leucine aminopeptidase in the outer root sheath throughout keratogenous zone and in the germinal matrix may reflect the high level of the metabolism, although little was known about the physiological significance of this enzyme.

The asymmetric distribution of alkaline phosphatase in the follicle bulb in the sheep was reported by LYNE and HoLlis. ${ }^{22)}$ They suggested the distribution of alkaline phosphatase might be related in some way to the formation of the bilateral segmentation of the fiber cortex and perhaps crimping. Moreover, the activity of the alkaline phosphatase is affected in the molybdenotic animals, decreasing in the liver and increasing in the kidney and intestine of rat. On the contrary to the expectation, the follicle bulbs with the asymmetric distribution of alkaline phosphatase was not found. Also the change of the enzymatic activity was not detected in this study.

Further investigations will be necessary for understanding the effect of Mo on the alkaline phosphatase activity because of the possibility that both activity and localization of the enzyme in the follicle may change from time to time in the continuously growing fibers.

We wish to thank Dr. Shoji UEsaka for his valuable suggestion, Dr. Masaru Kato, Faculty of Science, Kyoto Univ., for his constant encouragement and effort to provide the facilities and equipments, and also Mr. Toshiro Kamrya for reading the manuscript.

\section{References}

1) Dick, A.T., Aust Vet J 30: 196-202. 1954.

2) Wynne, K.N., and G.L. McClymont, Aust J Agr Res 7: 45-56. 1956.

3) Underwood, H.R., Trace Elements in Human and Animal Nutrition 3rd ed. 116-140. Academic Press. New York and London. 1971.

4) Marston, H.R., Proc Symp on Fibrous Proteins 207-214. Soc Dyers Coleurist. 1946.

5) Marston, H.R., Physiol Rev 32: 66-121. 1952.

6) Goldberger, R.F., C.J. Epstein, and C.B. Anfinsen, J Biol Chem 238: 628-635. 1963.

7) Singer, C.F., and E. B. Krarney, The Proteins vol. 2 part A 135-160. Academic Press. New York. 1954.

8) Mercer, E.H., Keratin and Keratinization 272-275. Pergamon Press. Oxford. 1961.

9) HoRIo, M., and Y. Kondo, Text Res J 23: 373-386. 1953.

10) Fraser, R.D. B., and G.E. Rogers, Aust J Biol Sci 8: 288-299. 1955.

11) Burley, R.W., and F.W. A. Horden, Text Res J 30: 484-489. 1960.

12) Gillespie, J.M., Aust J Biol Sci 17: 282-300. 1964.

13) Burley, R.W., and F.W. A. Horden, Text Res J 31: 389-398. 1961.

14) Burley, R.W., Text Res J 30: 473-484. 1960. 
Histochemical Studies of the Skin and Wool

15) Gomori, G., Microscopic Histochemistry 175-189. Univ. Chicago Press. Chicago. 1952.

16) Burstone, M.S., and J.E. Folk, J Histochem 3: 217-226. 1956.

17) Fraser, R.D.B., and G.E. Rogers, Proc Int Wool Text Res Conf Aust F: 151-155. 1955.

18) Montagna, W., The Structure and Function of Skin 2nd ed. 174-267. Academic Press. New York and London. 1962.

19) Auber, L., Trans Roy Soc Edinb 62: 191-254. 1950.

20) Brawn-Falco, O., The Biology of Hair Growth 65-87. Academic Press. New York. 1958.

21) Bersaques, J.DE., and S. Rothman, Nature Lond. 193: 147. 1962.

22) LYNE, A.G., and D.E. Holl.1S, J Invest Derm 48: 197-199. 1967.

\title{
モリブデン多給羊における羊毛および皮㲊組織 についての組織化学的研究
}

\author{
石田直彦・川島良治
}

京都大学農学部, 京都市, 606

\footnotetext{
羊に高レベルでMoを与えると銅欠之症と同菲の症状 交し，羊毛の特性である crimp が消失する。一方い わ㠴る fine wool においては, オルソ・ハラ両コルテ ックスより成る瀻維のパイラテラル楧造が wool crimp の形成と深く関連し酉っている、本研究は, Mo 多給が 羊毛瀻維構造ならびに皮下組織に対して及ぼす影響につ いて挨討しまたこの様な条什下ての wool follicle 附 近の代謝活性に関連して苦炸の酵素群（フルカリ性フォ スファターゼ・ロイシンフミノペプチダーゼ)の活性分布 を検討するために行われた，倛試メン羊は日本コリデー 儿種去勢羊 4 頙を用い，2頭に $200 \mathrm{mg} /$ 日碩のモリブデ ン酸アンモンを与え，2頭を対照として飼育し，8力月後
}

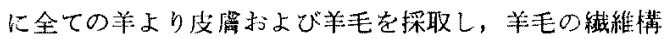

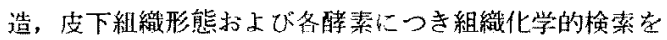
行ったてその結果，Mo投与により明らかにwool crimp の減少ないしは消失がみられ，羊毛瀻維のコルテックス は，バィラテラルでない变則的な染色像宗した。これ らの楧造注，毛根部のケラチン化带部上り分化してきて おり，またこの付近の内根鞘に扎いても不規則的京染色 像を淧好た。一道の酵素群の活性分有に対して Mo 投 与の目立った影響は認めら九なかったが，毛乳䫓・ケラ チン化带付近の毛根鞘に強く局在しており，この部分で の物質代謝が旺盛であることを暗示している。 


\section{Explanation of figures}

Fig. 1. Wool from control (CN10 and CN757) and Mo treated sheep (MN7 and MN77) showing loss of crimp.

Figures 2 and 3 show the bilateral segmentation in the fiber cortices of control sheep.

Fig. 2. Cross section of wool stained with methylene blue. Uptake of basic dye is confined to the ortho cortex. $\times 400$.

Fig. 3. Longitudinal section of wool. Note that the ortho cortex is consistently disposed on the outside of the fiber curvature. $\times 200$.

Figure 4 to 6 show the irregular segmentation in the fiber cortices of Mo treated sheep. Stained with methylene blue.

Fig. 4. Cross sections of wool. The para segment is divided into two pieces by the ortho cortex. $\times 400$.

Fig. 5. Cross sections of wool. The considerable number of the fibers reveal the irregular segmentation $\times 200$.

Fig. 6. Longitudinal section of wool. $\times 200$.

Figure 7 to 9 are cross sections at various levels of wool follicle of control sheep. Stained with methylene blue.

Fig. 7. Section across the lower portion of the follicle bulb. The center part of the section is the dermal papilla. The follicle matrix is stained more readily on the ectal side of the bulb deflection (arrow). $\times 400$.

Fig. 8. Section from the level just below the keratogenous zone. $\times 400$.

Fig. 9. Section from the upper level of the keratogenous zone. Note that the para cortical segment occurs on the thin side of the inner root sheath. $\times 400$.

Figure 10 to 12 are the sections of wool follicles of Mo treated sheep through the level of the keratogenous zone showing irregular cortical segmentations. Stained with methylene blue.

Figs. 10 and 11. Cross sections of the wool follicles. The basophilic response occurs in the peripheral or random parts of the cortices without relation to the inner root sheath. $\times 400$.

Fig. 12. Longitudinal section from the level at which ortho and para cortical cells are differentiated. $\times 200$.

Figure 13 to 15 are the sections of the skin of Mo treated sheep showing amino peptidase activity.

Fig. 13. Longitudinal section of the follicle from the keratogenous zone. The particularly intense activity is observed in the outer root sheath. $\times 150$.

Fig. 14. Longitudinal section of follicle bulb. The cells of the outer root sheath and the matrix are strongly positive for enzymatic activity. $\times 200$.

Fig. 15. Longitudinal section of the skin. Enzymatic activity is observed in the epidermis and in the peripheral cells of the sebaseous gland. $\times 100$.

Figure 16 to 18 show the localization of alkaline phosphatase in the follicle of Mo treated sheep.

Fig. 16. Cross section from upper bulb region showing enzymatic activity in the capillaries a round the follicle. $\times 200$.

Fig. 17. Longitudinal section of the follicle. Enzymic activity is observed in the irregular network of the blood vessels around lower part of the follicle. $\times 200$.

Fig. 19. Longitudinal section of the follicle bulb. Enzymic activity is shown in the complex network of capillaries in dermal papilla. Note also enzymic activity in dermal papilla cells. $\times 400$. 
Histochemical Studies of the Skin and Wool

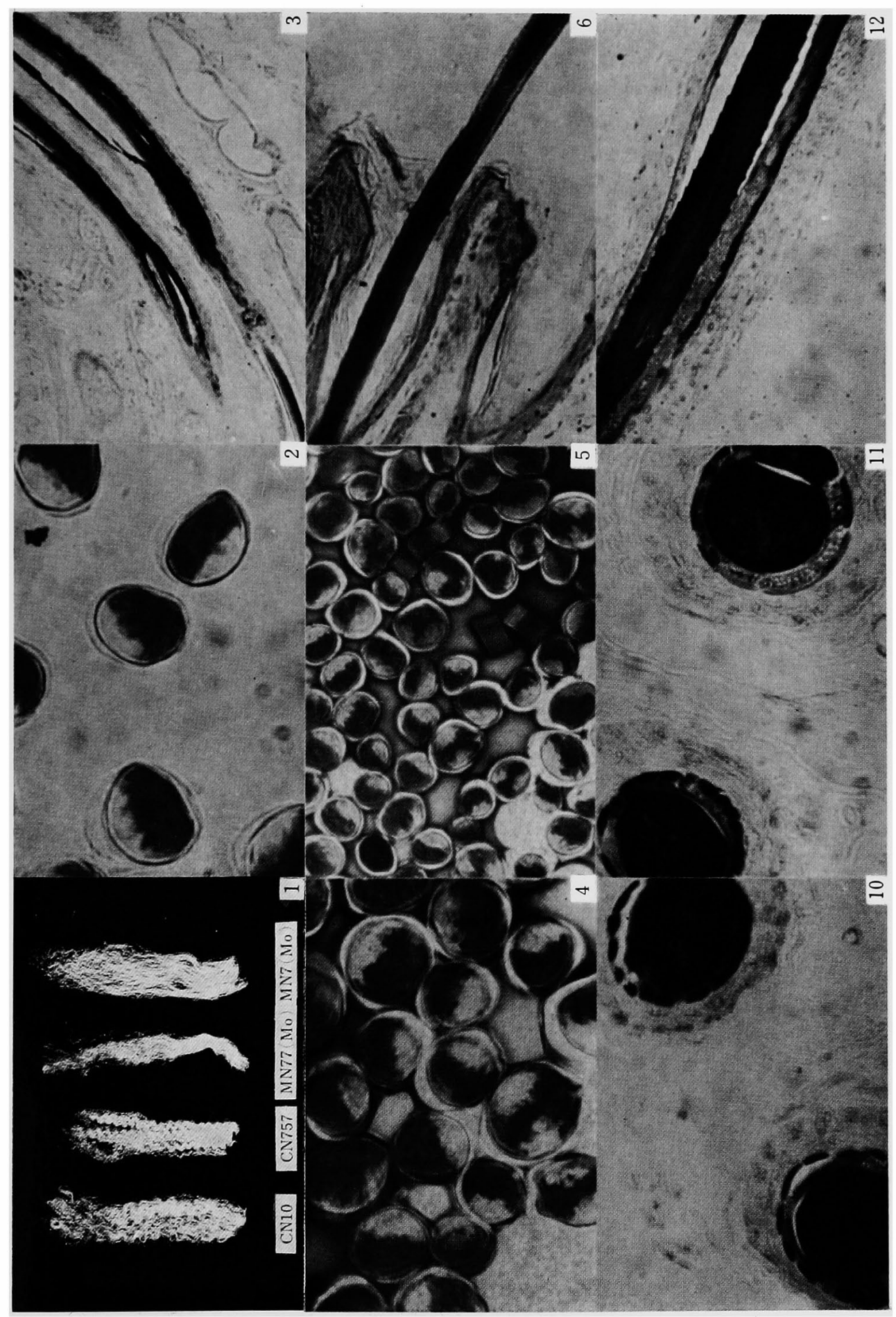




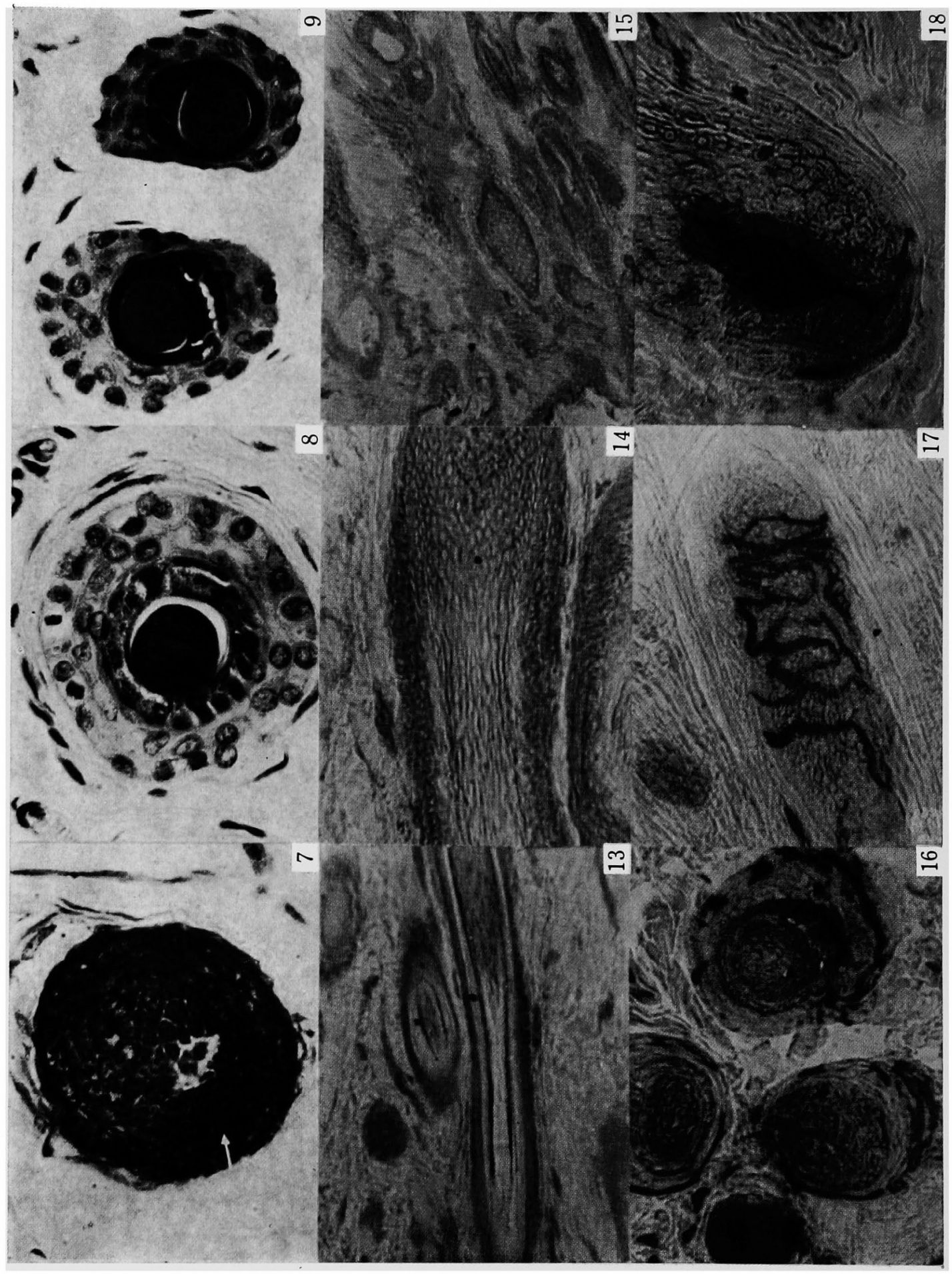

